\title{
Designing a mechanism for generating confidence in crowdlending platforms
}

\author{
Evgeny Popov ${ }^{1,4}$, Sergey Fedoreev ${ }^{3}$, Anna Veretennikova ${ }^{1,2,4, *}$ \\ ${ }^{1}$ Ural Institute of Management of the Russian Presidential Academy of National Economy and Public \\ Administration, 620144, ul. 8 Marta, 66, Ekaterinburg, Russia \\ ${ }^{2}$ Institute of Economics of the Urals Branch of the Russian Academy of Sciences, 620014, ul. \\ Moskowskaya, 29, Ekaterinburg, Russia \\ ${ }^{3}$ The Representative Office of the Sverdlovsk Regional Fund for Entrepreneurship Support in the \\ Gornozavodsky Administrative District, Nizhny Tagil, Russia \\ ${ }^{4}$ The Ural Federal University the Ural Federal University named after the first President of Russia B. \\ N. Yeltsin, Ekaterinburg, Russia
}

\begin{abstract}
The development of the equity economy as a new business model, the spread of digital platforms, as well as the task of increasing the efficiency of resources, stimulated the development of new financial instruments, including crowdlending. At the same time, lack of sufficient accumulated experience, both in the functioning and regulation of crowdlending platforms, significantly limit their activities. The purpose of this study is to design and substantiate the mechanism of confidence generation in crowdlending platforms. In the course of the study, the peculiarities of the equity economy functioning, which are characteristic, among other things, for crowdlending platforms, were described, regulatory, technical and reputational risks of confidence loss in the subsystems of the "platform-borrower", "platform-investor" and "loan-investor" relationships were identified, and tools for their reduction in these subsystems were proposed. In addition, an author's model of interaction between actors of the pooled investment market when investing by a loan provision has been developed, which includes the function of a collateral operator to represent the interests of investors in a one-to-many relationship. The theoretical significance of the results obtained consists in the expansion of scientific research in the field of the sharing economy to the financial resources market. The practical significance of the indicated results consists in the possibility of implementing these proposals to increase the level of confidence in crowdlending platforms.
\end{abstract}

\section{Introduction}

Currently, digital platforms (sharing platforms, search engines, social networks, ecommerce platforms, etc.) and the platform ecosystems formed by them are transforming entire industries and various types of socio-economic activity, becoming drivers of economic growth, innovation and competition [1]. Some industries have already faced a significant

\footnotetext{
*Corresponding author: vay_uiec@mail.ru
} 
transformation of pricing and demand in the market due to the emergence of platforms that provide the possibility of collective use of resources in the format of $\mathrm{p} 2 \mathrm{p}$ interaction, in such areas as, for example, passenger transportation (BlaBlaCar, Yandex.Taxi), logistics (pooling, pallet), rental of accommodation facilities (Airbnb, Booking) and e-commerce (Amazon, Ozon) [2]. A similar transformation is taking place in the market of alternative financial instruments in the p2p lending segment, while the transformation vector is aimed at converting instruments in this segment to forms identical in their consumer qualities to stock market instruments [3].

The study of platforms providing the possibility of resource sharing in the format of $\mathrm{p} 2 \mathrm{p}$ interaction, as objects of the sharing economy, for prerequisites of their emergence and sustainable development shows that the markets on which the platforms operate have common features: the availability of free resources from one of the parties to $p 2 p$ interaction, the participation of a wide range of independent actors from resource providers and their users, mutual confidence of actors, online interaction of the parties [3, 4].

The main issue in the development of $\mathrm{p} 2 \mathrm{p}$ lending platforms is the mechanism for ensuring mutual trust of actors on platforms in the subsystems platform-borrower, platforminvestor and borrower-investor. When studying the mechanisms of confidence generation in the subsystems of platform interaction, the issue of regulating the activities of platforms deserves special attention. The emergence of platforms whose functioning is not clearly defined in terms of current legislation creates prerequisites for regulating the activities of both the platforms themselves and the activities of their users. An illustrative example is the emergence of the BlaBlaCar service and its impact on the attitude of the regulator responsible for the safety of passenger trucking to transportation by private individuals. The operation of platforms can lead to explosive growth of markets, the administration of which was previously considered as being impractical due to its insignificant volume or high overhead costs. Consolidation of market participants around the platform creates additional opportunities for the regulator, creating conditions for reducing administration costs in specific markets [5-7].

With reference to the above mentioned, the purpose of this study is to design and substantiate the mechanism of confidence generation on crowdlending platforms. To achieve these goals, the features of the functioning of the equity economy platforms were described, the identification of risks that arise in the subsystems of crowdlending platforms was carried out, the measures to reduce these risks were proposed, and an appropriate document was designated, the use of which will increase the level of confidence.

\section{Foreign and domestic experience of crowdlending development}

The economic experience of collaborative consumption of goods for limited periods of time, which underlies the sharing economy, is not a fundamentally new phenomenon. However, the dynamism and high "penetrating power" of the spread of such relations to completely different objects of property and areas of their use, as well as the global scale of business models in the activities of platforms for collaborative consumption of goods, which have been manifested since the beginning of the XXI century, help us to reveal the development of a new specific model of economic relations.

For the first time, the description of the economic experience of "collaborative consumption", based on the possibility of collective use of goods and services on temporary lease rights instead of property rights, was presented in 1978 by M. Felson and J.L. Spaeth [8]. The modern spread of the term "sharing economy" originates in the work by L. Lessig [9]. The author claims that with the spread of the Internet, the economy has become "hybrid": 
more and more people refuse to pay for the opportunity to own goods in favor of the willingness to make more complex transactions in order to get the opportunity for temporary use [8]. R. Botsman and R. Rogers [10] describe the concept of collaborative consumption as a completely new socio-economic model that changes the pattern of traditional markets for the consumption of goods and services. At the same time, the joint consumption of resources can also be extended to the financial sphere. So temporarily free funds are an object that can be transferred for temporary use through crowdlending platforms.

Considering crowdlending platforms as an object of sharing economy, it is necessary to note the fundamental novelty of the relations arising in the economic practice of collaborative consumption of goods through platforms, which consists in the concentration of the dominant role and functions in transactions not client- or seller-based, but based on a virtual platform that ensures their interaction.

Among the criteria of the operational behavior of these platforms, the following should be noted:

- the widespread goods available to a significant number of potential owners become the objects of collaborative consumption as economic goods;

- the users of economic benefits of collaborative consumption have the choice of acquiring the benefits of ownership or buying the rights of short-term use;

- the remote and, often, impersonal nature of the contractual relationship between the buyer and the seller is realized;

- the virtual platform, when performing its intermediary functions, standardizes the context of the contractual relationship between the buyer and the seller;

- the scale of the variety of benefits of collaborative consumption - compared with the usual and understandable practice of renting expensive and rare material assets, modern solutions offers potential for the possibility of turnover of a wider list of benefits in the form of services, places, qualifications, information and solutions;

- the scale of the circle of participants, which is associated with a low entry threshold, realizes the prospects of participation in economic relations of collaborative consumption for the broad strata of the population.

Thus, the central object of the research in the analysis of the economic experience of collaborative consumption of goods becomes the activity of the virtual platform and its relationship with the entire spectrum of stakeholders. World experience clearly shows that the role of platforms providing the possibility of collaborative consumption of resources in the format of $\mathrm{p} 2 \mathrm{p}$ interaction is growing, demonstrating high growth dynamics in the amount of money turnover and the number of users. The volume of the global sharing economy will reach 335 billion by 2025, whereas in 2014, the global sharing market was estimated at $\$ 15$ billion. According to the study by RAEC and TIAR Center, the volume of the economy of joint consumption in Russia for 2020 amounted to 1.07 trillion rubles. The annual growth of the sharing services market amounted to $39 \%$, which means a slight slowdown in growth: in 2019 this economic sector grew by $50 \%$ to 770 billion rubles, compared to the previous year.

Experience of attracting pooled investments has received a general terminological fixation through the concept of "p2p lending" or "peer-to-peer lending» is a way of lending money to unrelated persons or "equal parties" without involving a traditional financial intermediary, for example, a bank or other conventional financial institution. Loans are provided online on the websites of authorized lending organizations through a variety of lending platforms and tools checking credit worthiness. [11,12]

When comparing the specifics of the work of crowdlending platforms with the activities of other entities of the sharing economy, also functioning in the format of $p 2 p$ interaction [13], an essential similarity of the internal nature and transactions mechanism is revealed. Money, as an economic benefit attracted for temporary use, is inherently not only a universal 
means of payment, but an ideal commodity, since in comparison with real assets they have the ability to exchange for any goods.

Thus, it is possible to consider the turnover of money as a specific commodity not as a fragmentary and special case of commodity turnover, but, on the contrary, as a universal and most universal type of economic goods. The validity of the conclusion is confirmed by a number of publications, and the term "sharing economy" itself is proposed to be considered as a generalizing umbrella term covering a wide range of activities based on digital platforms, including $\mathrm{p} 2 \mathrm{p}$ lending and other forms of Internet lending [14].

The first crowdfunding platform Fundable.com appeared in 2005. This is a website that attracts many independent venture investors to finance entrepreneurial projects. A similar logic is implemented in the work of a well-known site Kickstarter.com, which since its launch in 2009 has raised funding for almost 200 thousand projects in the total amount of 5.7 billion dollars.

It is natural, that with the development of the sharing economy in general and crowdlending platforms in particular, the interest of state institutions in its legislative design and regulation increases. The authors of the report "A European Agenda for The Collaborative Economy", published by the European Commission in 2016, recommended not to restrict online trading platforms, but stressed that sharing platforms do not have the right to distribute illegal information and violate copyright. The authors also note that if the EU countries find the right approaches to the shared consumption market, in the future it will be able to increase the volume of the EU economy by 160-572 billion euros, i.e. by about $2 \%$ (according to the IMF, the total volume of European GDP in 2019 amounted to 20 trillion euro).

The formal history of crowdlending in Russia is counted from the moment of signing FZ259 dated August 2, 2019 "On attracting investments using investment platforms". The most important provisions of this law are as follows: the operator of the investment platform must be included in the register of the Central Bank of the Russian Federation; one unqualified investor cannot invest more than 600 thousand rubles per year; the operator of the investment platform is not liable for the obligations of persons promoting investments; the operator of the investment platform is obliged to provide annual reports on the results of its activities for the organization of investment promotion. The adoption of this law indicates that the sphere of promoting alternative sources of funding in Russia is under state control. The indicated law, on the one hand, introduced a number of restrictions for crowdlending and crowdinvesting platforms, on the other hand, contributed to the dissemination of information about this method of attracting and investing funds, which favorably affected both the growth of demand in the form of an increase in the base of not only investors, but also borrowers, as well as the number of crowdlending platforms. At the same time, the lack of established practice, including legal practice, in resolving disputes between transaction participants, the novelty of this type of activity and the presence of non-confidence of new financial instruments have created the need for a more detailed analysis of emerging risks, as well as the development of mechanisms to ensure confidence on crowdlending platforms.

\section{Methodology}

The procedure of this study includes three main stages. At the first stage, the risks arising on the crowdlending platform were identified and systematized. It is important to note that the risks arising from the interaction of actors can be divided into three groups: regulatory risks associated with the platform operator's compliance with the requirements of the regulator and with changes in regulation; technical risks due to the operability of the platform and access to it; reputational, caused by the provision of false information by the parties, unlawful disclosure of information or non-compliance with obligations under contracts entailing 
reputational consequences for the other party [7, 15, 16]. In addition, at this stage, three subsystems were taken into account in which the risk arises: "platform-investor", "platformborrower", "borrower - investor".

At the second stage, an analysis of the identified risks was carried out, including the determination of the risk factor, the interaction subsystems, the consequences of the implementation of this risk, and a tool for its reduction was proposed. The result of this stage was a list of institutional solutions to identify the specified risks.

At the third stage, a mechanism for the functioning of the crowdlending platform was developed, taking into account the designated institutional solutions aimed at increasing the level of confidence of the interacting participants.

The database of the research includes scientific sources presented in the WoS and Scopus databases, the register of investment platforms formed by the Central Bank of the Russian Federation, regulatory legal acts regulating the operation of the crowdlending platform www.vdelo.pro, assisted by the participation of the Sverdlovsk Regional Entrepreneurship Support Fund, as well as official websites of other crowdlending platforms.

\section{Results}

\subsection{Risk research in the "platform-borrower" subsystem}

As to the regulation of the activities of crowdlending platforms, the following requirements and restrictions are applied in world practice: the admission of crowdlending platforms to the market by the regulator through licensing activities or inclusion in registries, limiting the volume of investment for hotel categories of investors for 12 months, limiting the volume of investment depending on the qualifications of the investor, requirements for operators of investment platforms to verify the borrower's business.

In the subsystem of interaction "platform-borrower" in the context of regulatory risks, the main risks are borne by the borrower. Such risks are caused by possible restriction of the market access to the platform operator or borrower. Taking into account the fact that the number of investors in the project is unlimited, at the same time, the service for calculating payments and distributing payments among investors is carried out on the side of the investment platform, the consequence of the restriction of the operator's access to the market by the regulator of the platform is an increase in the borrower's costs for servicing the loan attracted using the crowdlending platform.

Technical risks, such as failures in the operation of the platform or lack of access to the platform, are the result of untimely fulfillment of obligations under the contracts by the interacting parties: untimely receipt and distribution of funds, untimely informing the parties about changes in the essential terms of the loan.

The main risks of the platform in the platform-borrower subsystem are associated with non-fulfillment or improper fulfillment of obligations under contracts with investors by the borrower. This risk arises regardless of the quality of services provided by the operator of the investment platform, and can be reduced by implementing measures aimed at dividing confidence in crowdlending as a tool into two components - confidence in the operator of the platform and confidence in the borrower.

The investor, having no access to the data on the basis of which credit financial institutions make a decision on lending (bank statements, credit history of the borrower, the borrower's and founders' directors), can use only publicly available information about the borrower's experience and business reputation, integral characteristics calculated by the platform, such as the rating of the project or the rating of the borrower. In the subsystem of the "platform-borrower" relationship, there may be a situation in which the borrower 
influences the integral characteristics of the project by manipulating financial reporting data, information about securing the loan agreement, and other information about the project being implemented, thus misleading the investment platform. In this case, the platform carries reputational risks. Such risks can be reduced or eliminated by forming an integral characteristic of the project based on the criteria, the cost of manipulations with which exceeds the benefits of the borrower.

\subsection{Risk research in the "platform-investor" subsystem}

In the "platform-investor" interaction subsystem, both actors are sensitive to regulatory risks, so the regulator can restrict access to the market for a certain category of investors or set investment limits for certain categories of investors. At the same time, one of the key signs of the $\mathrm{p} 2 \mathrm{p}$ lending market is the availability of free resources from one of the parties to $\mathrm{p} 2 \mathrm{p}$ interaction, the volume of which may decrease due to the actions of the regulator. Also, the restriction of investors' access to the market has an impact on the mass of actors in the pooled investment market, as one of the signs of the market.

In the context of technical risks for the investor, there are risks of receiving incomplete or unreliable information from the platform about the quality of the investment project and the creditworthiness of the borrower, risks of improper fulfillment by the platform of obligations to work with overdue debts under the loan agreement (if such an obligation of the platform is provided for by the agreement with the platform), risks of technical failures.

The borrower's failure to fulfill obligations to the investor, poor quality of investment projects on the platform, or poor quality of the platform's service for evaluating projects or dealing with overdue debts cause reputational risks in this subsystem. The investment platform is the most sensitive to reputational risks in this subsystem.

\subsection{Risk research in the "borrower-investor" subsystem}

Mutual credibility of actors interacting through investment platforms (crowdlending platforms) is a condition for sustainable operation and development of the pooled investment market. In the general structure of the relations of the platform actors, a subsystem of the "borrower-investor" relations can also be distinguished.

The regulatory risks discussed earlier are projected onto this subsystem as well. Technical risks in the subsystem are primarily due to the solvency of the borrower at the time of fulfillment of obligations.

In the subsystem of the "borrower-investor" relationship, the major risk of the investor is the borrower's failure to fulfill obligations under the loan agreement, which may be due to the borrower's bad faith, deterioration of his financial condition and other reasons. When this risk is actualized, the costs associated with the recovery of debt by an individual investor under a loan agreement may exceed the amount of investments. The investor's losses in the implementation of such a risk can be divided into two components: investment losses (including the investor's interest income), lost profits accumulated over the period from the date of termination of interest income accrual to the time of debt collection from the borrower. Reduction of potential losses is possible due to the provision of collateral by the borrower under the loan agreement in the form of security or liens. 


\subsection{Tools for increasing confidence in interaction subsystems}

Table 1 shows the risks arising in the relationship subsystems described above and the tools for increasing confidence in these subsystems that affect the interaction scheme of pooled investment market actors when investing by a loan provision.

Table 1. Risks and tools for increasing confidence in the subsystems of interaction between actors of investment platforms.

\begin{tabular}{|c|c|c|c|c|}
\hline Risk & $\begin{array}{l}\text { Risk- } \\
\text { bearing } \\
\text { actor }\end{array}$ & $\begin{array}{l}\text { Interaction } \\
\text { subsystem }\end{array}$ & Consequences & $\begin{array}{c}\text { Tool to increase } \\
\text { confidence/reduce risk }\end{array}$ \\
\hline \multicolumn{5}{|c|}{ Compliance risks } \\
\hline $\begin{array}{c}\text { Access } \\
\text { limitation to the } \\
\text { market of the } \\
\text { platform } \\
\text { operator }\end{array}$ & Borrower & $\begin{array}{l}\text { Platform } \\
\text { borrower }\end{array}$ & $\begin{array}{l}\text { Increasing the } \\
\text { cost of loan } \\
\text { administration }\end{array}$ & $\begin{array}{l}\text { Approval of the self- } \\
\text { regulation mechanism as } \\
\text { mandatory for the } \\
\text { crowdlending market }\end{array}$ \\
\hline \multicolumn{5}{|c|}{ Technical risks } \\
\hline $\begin{array}{l}\text { Platform } \\
\text { malfunction }\end{array}$ & Borrower & $\begin{array}{l}\text { Platform- } \\
\text { borrower }\end{array}$ & $\begin{array}{l}\text { Late performance } \\
\text { of obligations to } \\
\text { investors }\end{array}$ & $\begin{array}{l}\text { Agreement on assistance in } \\
\text { attracting investments }\end{array}$ \\
\hline $\begin{array}{l}\text { Borrower's lack } \\
\text { of access to the } \\
\text { platform }\end{array}$ & Investor & $\begin{array}{l}\text { Borrower- } \\
\text { investor }\end{array}$ & $\begin{array}{l}\text { Late performance } \\
\text { of obligations to } \\
\text { investors }\end{array}$ & Loan agreement (offers) \\
\hline $\begin{array}{l}\text { Investor's lack } \\
\text { of access to the } \\
\text { platform }\end{array}$ & Borrower & $\begin{array}{l}\text { Borrower- } \\
\text { investor }\end{array}$ & Loss of profit & $\begin{array}{c}\text { Investment assistance } \\
\text { agreement }\end{array}$ \\
\hline \multicolumn{5}{|c|}{ Reputational risks } \\
\hline $\begin{array}{c}\text { Default on the } \\
\text { borrower's } \\
\text { project }\end{array}$ & Investor & $\begin{array}{l}\text { Borrower- } \\
\text { investor }\end{array}$ & Investment losses & $\begin{array}{l}\text { Guarantee agreement; } \\
\text { Pledge agreement }\end{array}$ \\
\hline $\begin{array}{l}\text { Default on the } \\
\text { borrower's } \\
\text { project }\end{array}$ & Platform & $\begin{array}{l}\text { Platform- } \\
\text { borrower }\end{array}$ & $\begin{array}{l}\text { Additional costs } \\
\text { associated with } \\
\text { the collection of } \\
\text { overdue debts }\end{array}$ & Assignment agreement \\
\hline $\begin{array}{l}\text { Default on the } \\
\text { borrower's } \\
\text { project }\end{array}$ & Platform & $\begin{array}{l}\text { Platform- } \\
\text { investor }\end{array}$ & $\begin{array}{l}\text { Additional costs } \\
\text { associated with } \\
\text { the collection of } \\
\text { overdue debts } \\
\end{array}$ & $\begin{array}{l}\text { Pledge management } \\
\text { agreement; } \\
\text { Assignment agreement }\end{array}$ \\
\hline $\begin{array}{l}\text { Provision of } \\
\text { false } \\
\text { information by } \\
\text { the platform }\end{array}$ & Investor & $\begin{array}{l}\text { Platform- } \\
\text { investor }\end{array}$ & Investment losses & $\begin{array}{l}\text { Investment assistance } \\
\text { agreement }\end{array}$ \\
\hline
\end{tabular}

\section{Discussion}

Opportunities for the development of crowdlending platforms are due to relatively high potential profitability, a sufficient level of development of information and communication technologies for the organization of online interaction of all actors and low regulation of the activities of crowdlending platforms (non-credit financial organizations) in comparison with the activities of credit financial organizations. The limiting factor in the development of platforms, as noted above, is a relatively low level of confidence in the new financial instrument. 
Figure 1 shows the scheme of interaction of actors of the pooled investment market when investing by a loan provision. Confidence in the subsystem of the "borrower-investor" relationship in the proposed scheme of interaction is provided by the guarantee of third parties under the loan agreement and collateral. Collateral management (including state registration of encumbrance of collateral, as well as the sale of collateral) is carried out by a third party performing the functions of a collateral operator and acting on its own behalf in the interests of investors. The pledge operator is also a party to the pledge agreement with the pledger. The mortgagor can be either the borrower himself or a third party.

In the "platform-investor" subsystem, the technical risks of platform failures associated with the provision of false information by the platform are compensated by the obligations of the parties under the agreement on assistance in attracting investments, under which the platform is responsible for the quality of services provided for access to the information system and the reliability of information. Reputational risks associated with the borrower's non-fulfillment of obligations under the loan agreement are compensated by the obligations under the assignment agreement assumed by the operator of the investment platform.

In the "platform-borrower" subsystem, the risks of technical failures in the operation of the platform, which are borne by the borrower, are compensated by an agreement on assistance in attracting investments. The reputational risks of the platform in case of nonfulfillment of obligations under the loan agreement by the borrower are compensated by the obligations of the borrower arising to the operator of the investment platform in the event of the conclusion of the assignment agreement.

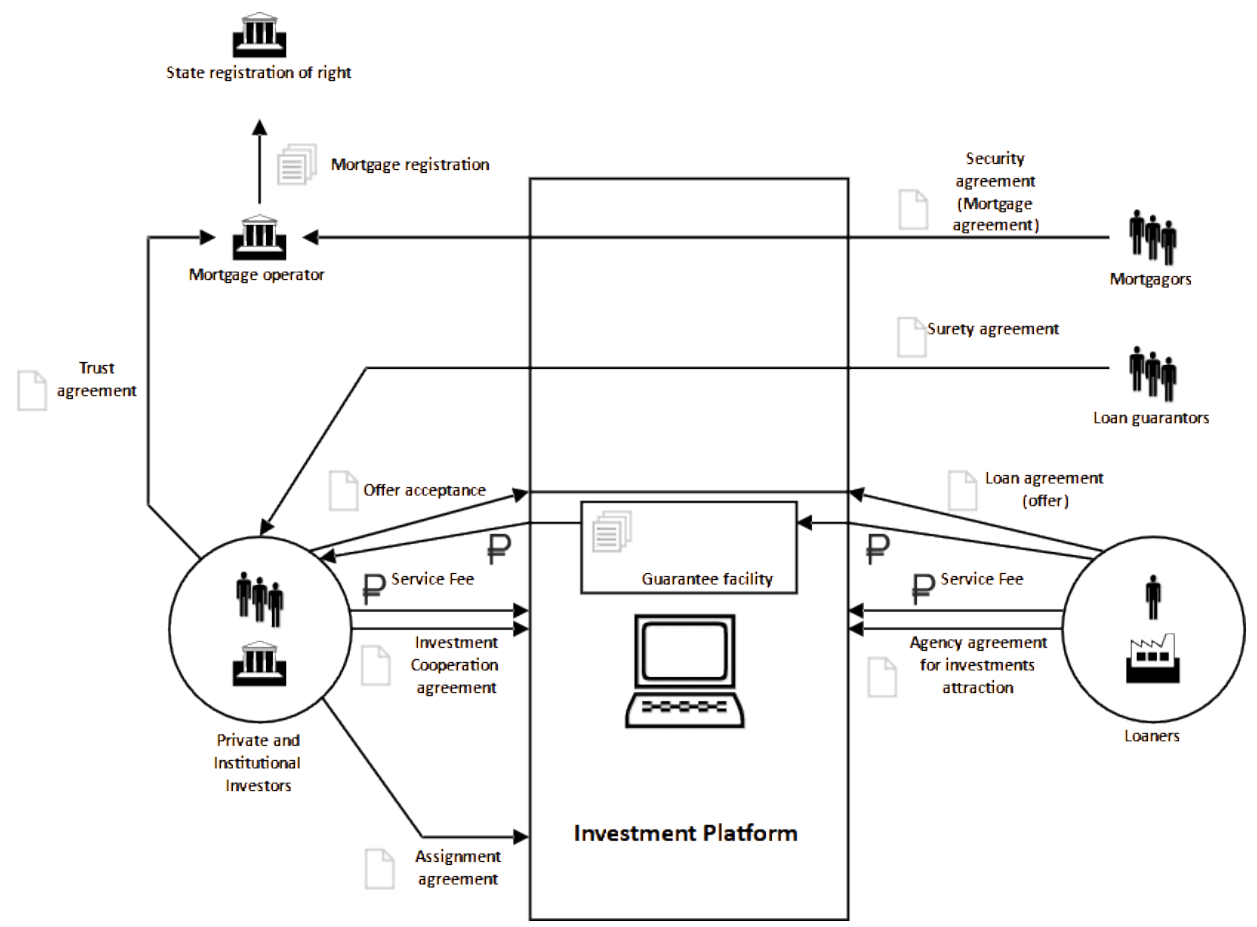

Fig. 1. The scheme of interaction of actors of the pooled investment market when investing by a loan provision.

Based on the consideration of the relationship subsystems, it can be concluded that there is a need for a separate analysis of the development of crowdlending platforms in the 
direction of building confidence in tools, services and mechanisms on the part of the platform itself and in the direction of providing services to the borrower for the borrower's independent work on generating confidence in the "borrower-investor" relationship subsystem. In other words, the platform should not generate confidence in the borrower, the functions of the platform are to generate investor's confidence in the platform tools, which provide the investor with the opportunity to obtain reliable data about the investment project and about the borrower, as well as to the mechanisms of the platform, excluding technical failures and hacking of the system.

\section{Conclusion}

In the presented study, in order to design and substantiate the mechanism of confidence generation on crowdlending platforms, the following results were obtained.

Firstly, the features of the functioning of the equity economy are described, which are characteristic, among other things, for crowdlending platforms.

Secondly, the risks of loss of confidence in the subsystems of the "platform-borrower", "platform-investor" and "borrower-investor" relationships have been identified and tools for increasing confidence in these subsystems have been proposed.

Thirdly, on the basis of the conducted risk research, the author's model of interaction of actors of the pooled investment market when investing by a loan provision has been developed, which includes the function of a collateral operator to represent the interests of investors in a one-to-many relationship.

The theoretical significance of the results obtained consists in the expansion of scientific research in the field of shared economy to the financial resources market. The practical significance of the indicated results involves the possibility of implementing these proposals to increase the level of confidence of crowdlending platforms.

\section{Acknowledgements}

The study was supported by the Russian Foundation for Basic Research, project No. 20-01000333.

\section{References}

1. M. Kenneya, J. Zysman, The platform economy: restructuring the space of capitalist accumulation, Cambridge Journal of Regions, Economy and Society, 13, 55-76 (2020)

2. H. L. D. Septiani, U. Sumarwan, L. N. Yuliati, K. Kirbrandoko, Understanding the Factors Driving Farmers to Adopt Peer-to-Peer Lending Sharing Economy, International Review of Management and Marketing, 10(6), 13-21 (2020)

3. M. Cumminsa, C. Mac an Bhaird, P. Rosati,T. Lynn, Institutional investment in online business lending markets, International Review of Financial Analysis, 71, 101542 (2020)

4. V. Bavoso, The promise and perils of alternative market-based finance: the case of $P 2 P$ lending in the UK, Journal of Banking Regulation, 21, 395-409 (2020)

5. E. Mason, Economic Concentration and the Monopoly Problem (Cambridge: Harvard University Press, 1957)

6. D. Dann, F. Hawlitschek, C. Peukert, C. Martin, C. Weinhardt, Blockchain and Trust in the Platform Economy: The Case of Peer-to-Peer Sharing, 15th International Conference on Wirtschaftsinformatik, Potsdam, German (2020) 
7. M. Felson, J. L. Spaeth, Community Structure and Collaborative Consumption: a routine activity approach, American Behavioral Scientist, 21, 614-624 (1978)

8. L. Lessig, Remix: making art and commerce thrive in the hybrid economy (New York: Penguin Press, 2008)

9. R. Botsman, R. Rogers, What's Mine Is Yours: The Rise of Collaborative Consumption (New York: Harper Collins Publishers, 2010)

10. A.-M. Moreno-Moreno, C. Sanchís-Pedregosa, E. Berengue, Success Factors in Peerto-Business (P2B) Crowdlending: A Predictive Approach, IEEE Access, 7, 148586148593 (2019)

11. C. Sanchís-Pedregosa, E. Berenguer, G. Albort-Morant, J. A. Sanz, Guaranteed Crowdlending Loans: A Tool for Entrepreneurial Finance Ecosystem Sustainability, Amfiteatru Economic, 22 (55), 775-791 (2020)

12. S. Pang, J. Yang, R.Li, J. Cao, Static Game Models and Applications Based on MarketSupervision and Compliance Management of P2P Platform, Mathematical Problems in Engineering, 8869132 (2020)

13. F. Slimane, A. Rousseau, Crowdlending campaigns for renewable energy: Success factors, Journal of Cleaner Production, 249, 119330 (2020)

14. M. Hesse, D. Dann, F. Braesemann, T. Teubner, Understanding the Platform Economy: Signals, Trust, and Social Interaction, 53rd Hawaii International Conference on System Sciences, 5139-5148 (2020)

15. M. R. Baye, J. T. Prince, The Economics of Digital Platforms: A Guide for Regulators. A Guide for Regulators, The Global Antitrust Institute Report on the Digital Economy, 34, 11 (2020). Available at SSRN: https://ssrn.com/abstract=3733754 